ESJ Humanities

\title{
The US State-Building Failure in Afghanistan
}

\author{
Osman Mohammed Afzal
}

Faculty of Public Governance, Budapest National University of Public Service, Budapest, Hungary

Doi:10.19044/esj.2021.v17n33p27

Submitted: 03 August 2021

Accepted: 23 August 2021

Published: 30 September 2021
Copyright 2021 Author(s)

Under Creative Commons BY-NC-ND

4.0 OPEN ACCESS

Cite As:

Afzal O.M. (2021). The US State-Building Failure in Afghanistan. European Scientific Journal, ESJ, 17 (33), 27. https://doi.org/10.19044/esj.2021.v17n33p27

\begin{abstract}
The almost nineteen years of international troops' presence and their support and donations to strengthen a democratic state in Afghanistan were in vain. The state-building process began with the toppling of a retrogressive regime, which was considered the base of al-Qaeda leaders who masterminded the 9/11 attacks in the United States. Within 20 years, the Afghan government could not use the opportunities made available by the international community and the US presence in the country. Although most criticisms are leveled at the United States for this state-building failure, on the contrary, its roots in Afghanistan can be precisely traced back to the central government. In other words, the state-building failure in Afghanistan has inner flaws. The blame is not attributable to its international allies regarding the fragility of the state and decay of democracy. This article illustrates how state-building at the pivotal centre of democracy failed in Afghanistan. The main hurdles of state-building are also scrutinised.
\end{abstract}

Keywords: State-building,NATO, fundamentalism, peace

\section{Introduction}

After the toppling of the Taliban regime in Afghanistan by the United States, state-building, rehabilitation, reconstruction, and ensuring peace began. Throughout a long period of war, the country was savagely ruined by civil war and the Taliban's retrogressive tyrannical regime. State-building was considered the country's key element, as most Afghan refugees returned home from neighboring countries and pinned their hopes on a secure and prosperous 
Afghanistan. However, step by step, all the hopes for peace and prosperity changed to despair. Somehow, one way or another, the Taliban re-emerged and developed a new approach including suicide attacks, bomb attacks in public places, terrorization of key political figures, the elimination of schools, clinics, and entire basic projects. Afghanistan is still a fragile country with no stable government to overcome challenges such as poverty and war against terrorism. Thus, a vicious phenomenon,fundamentalism, and the Taliban are still significant challenges in the country. Furthermore, poverty in Afghanistan has been the outcome of the continual war that has hampered the development process and economy for several decades. Fundamentalism is not the outcome of a weak economy. As Basil Siddique quotes Fukuyama: "Poverty is not the proximate cause of terrorism: The organizers of the $9 / 11$ terror plot came from relatively well-off backgrounds and became recruits of violent Islamism" (Siddique, 2012).

Except for the purposes of US intervention in Afghanistan, the aid for strengthening a united democratic state was a crucial opportunity for building a state with democratic values in the country.Thus, it is believed that the main factor that the US state-building failed in Afghanistan was the weakness and disability of the central government to make peace and build stability in the country. One of the hurdles that led the state-building process to fail is fundamentalism. The hegemonic sources of the Taliban and ISIS religious institutions have actively striven to change minds through institutions, none of which, in reality, have Islamic bases in society. These institutions (Darul Hefaz, Darul Madrassa, Darul Ulum, School of Haqnia, and Masques) are considered the hegemonic resources of fundamentalism and Talibanism in Afghanistan, and they are also actively defaming democracy, democratic values, and government. Although corruption has had a serious influence and has been a big hurdle for state-building development, religious institutions ideologically changed people's mindsets concerning government and democracy. The issue of concern of the article is finding out that despite the enormous amount of donations, how did the state remained fragile and how did the hegemonic resource of fundamentalism influence the failure of statebuilding?

\section{Methodology}

The September 9/11 attack in the United States and US intervention in Afghanistan and its efforts for state-building are broad topics. Abundant literature such as books, articles, films, reports, and documentaries exist regarding US state-building and the International Security Assistance Forces' functions in Afghanistan. This research has been conducted based on the qualitative method. However, most of the literature concerning the US intervention and state-building in Afghanistan was researched in a journalistic 
way. Therefore, to illustrate the hypothesis clearly, credible news reports and documentaries were used to a very minor degree in this article too. In addition, most of the data focuses on the state-building process by the United States in Iraq and Afghanistan, and also NATO's interventions with peacekeeping intentions. The US state-building failure and fundamentalism as the primary cause in Afghanistan were rarely discussed. However, the article's main argument is the failure of state-building and its significant elements. Based on secondary data, the authors' analysis concerning the fragility of the state after 2001 was corruption. On the contrary, fundamentalism as the main factor of state fragility in Afghanistan did not seem the focal point of the author's work. Thus, this article focuses on two dimensions: first, on the hypothesis of statebuilding failure, religion as the vital element of Afghan society and its influence. Second, on modern pattern incompatibility with Islam that disrupted state-building, and democracy institutionalization in the country.

\section{The United States Intervention in Afghanistan}

On September 11, 2001, a series of suicide attacks was carried out by members of al-Qaeda in the United States, most notably the destruction of the twin towers World Trade Center. Two thousand nine hundred seventy-seven people lost their lives during the attacks (Masud, 2008). The terrorist operation took place on US soil with various political, economic, security, and military consequences for the country and the international community. Later on, the nationalities of the hijackers who participated in the attacks became known: fifteen Saudi Arabian nationals, two United Arab Emirates nationals, an Egyptian citizen, and a Lebanese citizen (The 9/11 commission, n.d.).

After the attack, President George W. Bush decided to overthrow the Taliban regime in Afghanistan. The United States and its allies supported and initiated the Taliban regime's destruction in Afghanistan for harboring and supporting al-Qaeda's leader, Osama Bin Laden, who masterminded the 9/11 event. At the same time, the people of Afghanistan were also sick and tired of the tyrannical, repressive Taliban Emirate system. President Bush emphasizes that "true peace will only be achieved when we give the Afghan people the means to achieve their own aspirations. Peace will be achieved by helping Afghanistan develop its stable government" (Watson, 2012, p.171). Thus, the state-building by the United States in Afghanistan was part of the US mission that today shows that Afghanistan has at least a fledgling democracy.

The War on Terror operation by the United States in Afghanistan was aimed precisely at al-Qaeda's center and the Taliban, as the like-minded regime. Thus, Bush announced a global war on terrorism, chased al-Qaeda's top leaders, and had bombed their nest by December 2001. Eventually, by May 2011, Osama, the al-Qaeda leader, was found and killed by a US Navy SEAL team in Abbottabad, a city near Peshawar, Pakistan (Asthappan, 2016). 
All efforts by the world community focused on counter insurgency and peacekeeping in Afghanistan. Furthermore, the Karzai regime passively functioned to prevent the re-emergence of the Taliban. On the other hand, Karzai did not have experience in building institutions and governance. However, he had experience working with the Taliban and had ethnic ties with them. Therefore, the Karzai administration did not agree with the shift to counter insurgency (Tellis, 2009). The Taliban, as a result of the Karzai regime's weak policies, re-emerged in Afghanistan. The government did not recognize them as terrorists but instead called them "Dissatisfied Brothers." This strategy continued for more than a decade and ended with the sacrifice that took civilians lives that none of the leaders paid, but innocent people paid with their dear lives. Considering this, the United States eloquently, in January 2013, was told by the Afghan delegation in Washington that the Taliban, after 2014, would no longer be the enemy of the US, even if the US attacked Kabul. Unfortunately, it seems Washington and the rest of the world community realized that a massive amount of money had been spent on the military sector in Afghanistan, and yet there was no commitment to stability in the country (Neumann, 2015). Thus, what was still considered a big hurdle against statebuilding in Afghanistan, fundamentalism, ethnic sympathy with the Taliban, and rampant corruption that paralyzed the state institutionally, continued to exist.

Based on Brown University's findings, the cost of the war in Afghanistan from October 2001 to April 2021 has been estimated at 1.7 trillion or nearly two trillion US dollars. Of course, portions of this money were dedicated to strengthening and stabilizing Afghanistan. (Petersmann, 2021).

\section{ISAF and NATO in Afghanistan}

ISAF is the UN-mandated decision proposed in December 2001 in the Bonn agreement by the UN security council. The goal was to deploy international forces to support and assist the newly established Afghan government transitional authority, and pave the way for a secure environment (Stollenwerk, 2018). In August 2003, NATO undertook the command of ISAF and launched the International Security Assistance Forces. First, the assumption was to strengthen institutions in the capital focusing on five crucial key pillars: "Military Reform, Police Reform, Government Reform, Economic Reform, and Drug Growth Eradication." (Beljan, 2013).

The focal point of the ISAF's military reform was to educate and train the Afghan National Army and Police, while counter insurgency and peacekeeping were its main goals. Training, advising the Afghan National Army and aiding them in counter insurgency, and neutralizing insurgent networks went in tandem with the other fundamental projects in the country. Its definition of war was so evident - according to US Army General David 
McKiernan "The fact is that we are at war in Afghanistan. It's not peacekeeping. It's not stability operations. It's not humanitarian assistance, it's war.'(Tuck, 2014).

In this war, NATO roughly lost its 3,500 soldiers in establishing a state ruled centrally, under elected leadership whose purpose was to encompass democratic values, and emphasize the state's role as being responsible for human rights. However, the ideal democracy of the United States and its allies did not materialize as they had predicted. They had invested nearly 1 trillion US dollars, and they had lost 2,500 soldiers in supporting and paving the way for democracy in Afghanistan (Witter, 2016). The reality of war for the United States and its allies in Afghanistan was quite clear. Also, the supported government in Afghanistan had a vague sympathy for the Taliban. There was no definition of 'war' or 'enemy' in the country, even though Hamed Karzai called the Taliban 'brothers'. In general, one of the phenomena that the Taliban did not annihilate in Afghanistan was the weak approach of the government concerning the enemy (Sorkin, 2014).

\section{Resolute Support Mission}

After a dozen years of international military combat forces' presence in Afghanistan, considered as the United States' longest war in its history, the Afghan National Security Assistance forces in late 2015 took on the entire responsibility for the security of Afghanistan. The Resolute Support Mission in January 2015 replaced the International Security Assistance Forces Mission to continue its cooperation and role as counterpart with the Afghan National Armed forces. The Resolute Support Mission was trained to high standards, and the Afghan National forces were trained to combat terrorism professionally. The financial contribution to the Afghan National Security Forces and military institutions testified that it was NATO's profound commitment to the Afghan government (Salman, Tezel, Bayramog, et al., 2016). The RSM challenge was to handle the local irregular militias called the local Afghan police. The government wanted to control areas through the ALP who were not trained in military tactics and principles, but had the extraordinary duty of supporting the regular Afghan troops (Schreer \& Waldman, 2019). Although neither the Ghani nor the Karzai administrations had an offensive policy against the Taliban, Arbaki (ALP), however, as a support armed group, strongly sided with the Afghan National Army and Police. A force such as the ALP, which the Americans had already experienced in Iraq, was a grassroots initiative against al-Qaeda that they armed locals in Iraq and named them Sons of Iraq. They were para-military and are familiar with the geography of conflict in Iraq. Remarkably, they resolved the complexity of fighting for American troops (Abed \& Jensen, 2010). 


\section{Why did State-Building Fail in Afghanistan?}

There are abundant writings dealing explicitly and implicitly with the concept of state-building, which is genuinely an inter-disciplinary topic that encompasses social science, international relations, political studies, economics, security studies, and developmental studies. Most of the time, state-building is considered an interventionist strategy that strengthens or restores institutions, in general, to activate the apparatus of a state bureaucratically, as the United States did in Iraq (Zoe, 2007). However, the tangible outcome of state-building in Afghanistan by the Western world was the formation of a centralized system that in a multi-ethnic society such as Afghanistan is still a problematic issue. From the governance perspective, the centralized system is not conducive to fostering development and paving its way. On the contrary, a centralized State edifice and a rentier economy always allow capacities to rise, though the state has a massive dependency on foreign aid (Murtazashvili, 2019).

To illustrate the state-building challenges in Afghanistan, the three crucial inner factors that disrupted and hindered this process in the country should be explained. First, non-control over religious institutions changed into the hegemonic resource of terrorism and the Taliban. The second was the lack of transparency in foreign aid and the state as the only pebble on the beach, meaning that the leadership could not ensure trust between the state and the people (Edwards, 2011).

\section{Religious Institutions as the Hegemonic Sources of Fundamentalism}

The hegemonic sources of terrorism have always been active and have manipulated Afghan society preaching through the Madrasa and religious institutions under the government's patrimony, but against the government. These institutions were launched in Pakistan during the Jihad in 1979 against the Soviet Union, and more predominantly during the Taliban regime between 1994-2001 (Aljezeera, 2014). Thus, a lack of strategy in the government and absence of control of religious institutions, such as the Darul Hefaz, and Darul Madras $^{l}$ mosques which preach Islamic fundamentalism for the people, plunged the state into the quagmire of instability. Many pupils are given religious lessons in these institutions, and are easily manipulated and controlled by terrorist agendas. There is abundant evidence that most pupils either come from Pakistan or graduate from these institutions to be hired by the Taliban (Fuller, 1991).

Fundamentalism in Afghanistan has its roots during the war against the Soviet Union, predominantly because the Taliban regime only allowed the Madrasa to legally open during their administration (Roy, 2002). As a result,

\footnotetext{
${ }^{1}$ Religious institutions where pupils' study basic religious lessons.
} 
these institutions became hegemonic resources of terrorism and fundamentalism in Afghanistan, and they were underestimated by the regimes that had been supported by the United States since 2001 .

Over the past two decades since 2001, efforts towards democracy and its institutionalization have not succeeded in Afghanistan. Indeed, the roots of its failure revive people's apprehension about democratic phenomena after their defamation by the Imam's (clerics) group in the Madrasa and other religious institutions that constantly preached against democracy to change people's minds. According to them, democracy would cause Islamic values to fade in society, whereas terrorism, using the same narrative and the same arguments, slaughters people in certain Islamic countries (Larson, 2011).

Supremacy of Law:Governance with the soft strategy of manipulation and its aspirations to the rule of law in the nation has not been seen in Afghan government bodies since 2001, and authorities have only been constituted through military force. Afghan society has been governed ideologically by religious proxies such as clerics who are inclined to have retrogressive mentalities and preach to the people through the mosque, thus controlling people's mind. However, physically the society is being governed by the government through military force. First, it is imperative to remove and eradicate economic hurdles, terrorism, and fundamentalism. The eradication of fundamentalism in Afghanistan would signify structuring of the practice of religion and controlling religious institutions. As mentioned above, for one to become a spiritual leader or Imam, one must meet specific academic criteria and competencies. One way or another, mosques and Imams have been at the disposal of terrorism and fundamentalism. The plan ought to have come into force at the beginning of state-building in 2004. Such a scheme could have ridden the society of the clergy who do not know about Islam of Peace, but rather about fundamentalism to regress centuries to solve the problems of today. In modern governance, institutions have a crucial role to play, and this is how muslim reformist scholars found compatibility between Islam and modernity regarding social issues and institutions. They also believe in social progress and institutionalization of liberal elements such as democracy, social justice, equality, human rights, freedom of thought, expression, education, science and technology to guarantee development in Islamic countries. Ali Abd al Razig, concerning politics and governance, argues that "Islam is not against democracy and democratic institutions, and the values of Islam as brought and preached by the Prophet Muhammad were not concerned with the issues of politics and governance. He holds that Islam is a message and a religion and not a government or a state" (Yusuf \& Ali, 2012). Democracy is an available principle in Islam, though they are mutually compatible in the concept of collective decisions being taken by the masses for their political 
destiny, which in Islamic literature means Shura ${ }^{2}$. Muslim scholars clarified and solved the puzzle of a wrong belief from Islam that created a phobia by fundamentalist and terrorist groups in Afghanistan and some Islamic countries (Hofmann, 2004). The compatibility of today's phenomena in the name of modernity has its rationality in Islamic principles. However, this article aims not to find the compatibility of Islam with modernity. The most prevalent efforts to state-building in a failed state involved in a war against terrorism need to strengthen military capabilities, hard power, and ways of manipulation and the establishment of a broad hegemony. In other words, the government ought to have an interdependent relationship with the nation (Sadek, 1998).

The second challenge that blunted the state-building process in Afghanistan is corruption, which has been a crucial challenge from the very beginning of the new phase of state-building after 2001. In the last two decades, corruption has penetrated institutions in all parts of the state. Although numerous funds were allocated for corruption eradication by the USAID and devolved from some countries' anti-corruption efforts, the population was affected by unemployment and the lack of an economic sector and entrepreneurship to create jobs (Singh, 2016). The only option that people want to make a living is to work in the government. To achieve a governmental post, bribery became an inevitable custom in a society where there is no other lucrative organization to work for except the government. Consequently, clientelism dramatically erupts in governmental institutions with appointments in the government often happening either based on political relations or family affiliations. The vicious corrupt notion rooted in society is that one should know someone in the government body in order to be hired. In other words, we can say that this is a new version of nepotism (Dharmavarapu, 2015).

In 2015, the World Bank rated Afghanistan the fifth most impoverished country globally, reflecting the fact that unemployment and corruption adversely affected the country and entrepreneurs. Lack of bureaucracy and technology also paved the way for corruption. Afghanistan has a significant dependence on foreign aid, and this inflow of aid has contributed to widespread corruption (Mark \& Brick, 2010). Since 2001, during statebuilding, reconstructions, development and democratization, tremendous amounts of money have been donated for Afghanistan. All such donations have been somewhat looted by external and internal sectors in the country (Spenta, 2017).

\footnotetext{
${ }^{2}$ Shura or consultation is an instrument for reconstruction and reform, mentioned in the Qur'an and suggested in the practices of the Prophet Muhammad and his Companions (PBUH). Generally, it is a tool used by Muslim scholars and rulers or caliphs in arriving at a decision or ruling on particular matters or issues relating to the affairs of Muslims.
} 
From the period of state-building, multicultural states for well-being and good governance must first create mutual trust between the government and ethnics, and they should also strive for nationalism to encompass and observe the values of all minorities in the country. Equalities and justice among ethnic groups strengthen the political culture and pave the way for peaceful integration. State-building in the liberal context in a crippled, war-torn Islamic country is a challenging process. To know these hurdles, there needs to be a sociological outlook on society to recognize and understand precisely the acceptance of modern phenomena. Traditional society is a regressive society sunk in rough religious beliefs incompatible with new patterns (Zammin, 2018). According to Ibn Khaldun, the rural people's and urban dwellers' sentiments differ. Rural communities are united against unknown patterns, but urban communities are not. Except for religious patterns, traditional society does not readily accept modern ways such as democracy, freedom, and civil rights. Introducing these patterns into traditional societies needs strong relationships with people fostered by providing welfare and economic growth.

The third problem is the method of governance that caused the failure of democracy and state-building in Afghanistan. The failed rule of law, economic injustice, lack of reform, the pressure of unemployment, and most importantly, non-transparent elections are all contributing factors. However, criticism was leveled at the United States for imposing democracy in Afghanistan, affirming that people did not know democratic practices and ways at the outset (Enterline \& Greig, 2008). Since 2001, Afghan society has been governed by two powers: visible power (the government, the regular Army) and invisible power (religion) (Murtazashivili, 2016). The visible power ought to be government, but demonizing the Taliban or sanctifying them in the society was one of the causes why terrorism remained in the country. Admittedly, force or hard power are not the only way of governing to expand sovereignty in a state. Hard power instead is a threat of unlawfulness as well as the promise of maintaining independence, but developing authority only with military options is a false deliberation. Priorities of governance today are different and softer than before, and statesmanship is based on a democratic approach and sociological recognition. In Afghanistan, the primary hegemonic source of the government is purely the military institutions. Cultural, social, and political hegemonic source references in the society are absent. People are militarily under the control of the government, but ideally under the control of Islamic fundamentalism, whereas, in retarded communities, religion is a supportive phenomenon for helping people manage their lives (Forouzan \& Alishahi, 2018). 


\section{With Whom did the US Reconcile in Afghanistan?}

The Taliban formed in 1997 under the leadership of Mullah Mohammed Omar against the (Mujahideen) freedom fighters who withstood the Soviet invasion in 1979 (Weigand, 2017). The Taliban is a fundamentalist group whose school of thought is the same as Al Qaeda's and ISIS's (Anna, 2017). In other words, they are sipping from the same cup of fundamentalism and terrorism. Fundamentalism, mainly after the Soviet Union invasion, found its prominent influence under the Jihad aegis in Afghanistan. However, the foreign influence on fundamentalism in Afghanistan made it evident that the regional hegemonies were striving to proceed with the war in the country. Pakistan, Saudi Arabia, Iran, and Egypt have had ties with fundamentalist groups in Afghanistan since the Soviet Invasion. Egypt's Muslim Brotherhood regime did not have a specific political goal in Afghanistan, but they supported the tyrant regime of the Taliban due to the Islamic name of fundamentalism.

With the Afghan conflicts and the need to find a way to pull the country out of its current misery, it is necessary to put forward powers' broad interests and discuss their competitive policies for the region. The withdrawal of the US from Afghanistan is good news for neighboring countries of Afghanistan and regional authorities, specifically Iran and Pakistan. The US-Taliban peace agreement would temporarily diminish the conflict but will not bring stability to the country (Chaudhuri \& Shende, 2020). Somehow this deal leaves Afghanistan in the hands of the radical group that does not believe in human rights and freedom but in "Sharia law". Sharia cannot respond to today's quality of life and the priorities of the people. According to Donald Trump, "the Taliban could 'possibly' seize power after a US withdrawal from the analytical perspective. United States officialdom is not concerned if the Taliban seize power in Afghanistan" (Radio Free Europe, 2020).

The United States' longest war in Afghanistan has ended. On February 29, the US Taliban peace negotiations bore fruit, and both sides signed an agreement to end nearly nineteen years of war in Afghanistan. The primary US commitment for the Taliban was to complete their presence in Afghanistan within fourteen months, releasing five thousand Taliban soldiers from prison. Ultimately, 5000 thousand Taliban was released from the dungeon, and Americans are at the final stage of withdrawal from Afghanistan. However, at the same time, the conflict has been exacerbated. Furthermore, the Taliban agreed not to launch any attacks from the Taliban area on the US and to reduce violence against foreign troops (United States Signs Agreement with the Taliban, but Prospects for Its Full Implementation Remain Uncertain, 2020). 
'After the announcement of guarantees for a complete withdrawal of foreign forces and timeline in the presence of international witnesses and guarantees, and the announcement in the presence of international witnesses that Afghan soil will not be used against the security of the United States and its allies, the Islamic Emirate of Afghanistan which is not recognized by the United States as a state and is known as the Taliban will start intra-Afghan negotiations with Afghan sides on March 10, 2020, which corresponds to Rajab 15, 1441 on the Hijri Lunar calendar and Hoot 20, 1398 on the Hijri Solar calendar". The peace agreement for the Afghan government and people would be conditionally acceptable provided the Taliban renounces violence' (BBC, 2020).

President Trump predicted that the Taliban might try to gain power somehow through violence or after the US withdrawal. This quote shows that the US would not engage in case the Taliban attempts to take power. If the Taliban comes to power, either way, it is a reverse move for Afghanistan, creating an even stronger radicalism putting society in the hands of fundamentalists again. According to the most prevalent international school of thought, realist countries such as the United States never have permanent friends. President Trump said "Countries have to take care of themselves. You can only hold someone's hand for so long" (Kube, Dilanian \& Luce, 2020).

Afghanistan and countries such as Syria and Iraq in the Middle East face similar challenges, which are terrorism. The Islamic State (ISIS) was somewhat removed in the Middle East and did not negotiate with the US, but the United States did maintain a truce with a group from the same school of thought as Al-Qaeda and ISIS. In history, ideologies have never been subdued by soft approaches such as negotiations and diplomacy. Peace with an ideological group such as the Taliban, who do not attribute a nominal value to human rights and democratic values, would be a vain effort (Florian, 2017). Negotiations like today's signing of an agreement by the United States with the Taliban for peace in Afghanistan can never be successful. However, intraAfghan talks in Doha are focusing on peace with the Taliban. The Taliban emphasizes the Islamic Emirate system in the country, but no Afghan would accept such a precondition by the Taliban as a return to a dark period. According to John R. Allen, who led all the US and NATO forces in Afghanistan, "the Taliban are untrustworthy; their doctrine is irreconcilable with modernity and the rights of women; and in practice, they're incapable of summoning the necessary internal controls and organizational discipline needed to implement a far-flung agreement like this. The so-called "Agreement for Bringing Peace to Afghanistan"will not only not be honored by the Taliban, but will also not bring peace" (Allen, 2020). The intra-Afghan talks would be fruitful if the Taliban accepted two decades of achievements in 
human rights, media, and the fledgling democracy in the country. For the IntraAfghan dialogue, groups from all political parties and members of civilian society were shuffled together to negotiate with the Taliban.

\section{Conclusion}

The salient factors of the US state-building failure in Afghanistan comprise of restoring and strengthening a centralized political system in Afghanistan where decision making is the authority of an individual. A centralized system in a multicultural society such as Afghanistan with different minorities is not decent. It has been proven that such a system is not fair for multicultural societies, however weak it may be in tackling challenges in such a society. Still, the nationalistic policy of the government over the Taliban crucially gave them room to reintegrate themselves step by step. Neither Karzai nor Ghani had a vigorous policy for the demolition of fundamentalism and the Taliban in Afghanistan; rather on the contrary, they had sympathy with them. Both boosted the notion that the Taliban had the right to take control of parts of Afghanistan. They played a nationalistic policy over the Taliban to subdue them for the sake of peace. However, such a policy vehemently demoralized the Afghan National Army combating the enemy. Suppression and fighting against the Taliban were not based on an inclusive commitment by the government. The state-building failure in Afghanistan is multi-dimensional which is characterised by widespread corruption institutionally, lacking transparency concerning foreign aid, and overlooking radical institutions by the government. Thus, Afghanistan is still a fragile state, dependent on a rentier economy that since 2001 has created the minimum capacities in the country. However, the state still cannot fund its institutions' expenditure through its domestic income. War and weakness of the state in Afghanistan is the outcome of interfering with regional and global hegemonies' rivalries. It is evident that this aspect of the war in Afghanistan needs broad research and discussion.

Overall, the Taliban peace deal with the US complicated the situation in Afghanistan, even with the premise that if the Taliban gets the power in the country, what will happen with the minor achievements of the nineteen years of fledgling democracy in the country? Most of the assumptions are based on these two questions. That new chapter of war would begin in Afghanistan against the "Islamic State", and the peace negotiations of the Taliban and the Afghan government would still be unrealized. 


\section{References:}

1. Abed Al-Jabouri, N. \& Jensen, S. (2010). The Iraqi and AQI Roles in the Sunni Awakening, Journal of the Center for Complex Operation, p. 13, https://www.files.ethz.ch/isn/133906/Prism\%202-1.pdf

2. Aljezeer, (2014) The Rise of Fundamentalist Madrassas In Northern Afghanistan [video]https://youtu.be/vHWuj0SWs84

3. Allen, R. J. (2020). The US-Taliban agreement, Brookings https://www.brookings.edu/blog/order-fromchaos/2020/03/05/around-the-halls-brookings-experts-discuss-theimplications-of-the-us-taliban-agreement

4. Anna, T. (2017). Islamic State, The Taliban and Al-Qaeda: How Are They Different from, https://www.forces.net/evergreen/islamic-statetaliban-and-al-qaeda-how-are-they-different

5. Asthappan, J. (2016). The Cost of War: Weighing Civilian Losses in the Afghan War SAGE Open, 6(1), 6/1/2158244016640590-. doi: $10.1177 / 2158244016640590$

6. BBC, Afghan conflict: US and Taliban sign deal to end 18-year war https://www.bbc.com/news/world-asia-51689443

7. Beljan, R. (2013). What lessons from ISAF operations can be drawn for the UN PKOS, Peace Operation Training Institute, p. 9 https://cdn.peaceopstraining.org/theses/beljan.pdf

8. Chaudhuri, R. \& Shende, S. (2020). Dealing With the Taliban: India's Strategy in Afghanistan After US Withdrawal, Carnegie India, https://carnegieendowment.org/files/Chaudhuri_Shende__Afghanistan.pdf

9. Deharmavarapu, R. (2015). Corruption and Graft in Post-Conflict Afghanistan, Inquiries Journal of Social Science, Vol. 7 No. 07 http://www.inquiriesjournal.com/articles/1057/corruption-and-graftin-post-conflict-afghanistan

10. Edwards, L. (2010). State-building in Afghanistan: A case showing the limits? International Review of the Red Cross, 92(880), 967-991 doi:10.1017/S1816383111000099

11. Eggerman, M. \& Panter-Brick, C. (2010). Suffering, hope, and entrapment: Resilience and cultural values in Afghanistan, Social Science \& Medicine, Vol. Volume 71, Issue 1, https://doi.org/10.1016/j.socscimed.2010.03.023

12. Enterline, A. \& Greig, J. (2008) Against All Odds? The History of Imposed Democracy and the Future of Iraq and Afghanistan, Foreign policy Analyse, Vol. 4,8-5

13. Forouzan, Y. \& Alishahi, A. (2018). Terrorist movements in Afghanistan. Attitudes towards the status of radical fundamentalist 
forces in Islamic post awakenings Sociology International Journal, DOI: 10.15406/sij.2018.02.00135

14. Fuller, G. (1991). Islamic Fundamentalism in Pakistan: Its character and prospect, National Defense Research Institute, pp.17-20, ISBN:08330-1082-4, https://www.rand.org/content/dam/rand/pubs/reports/2007/R3964.pdf

15. Hoffman, S. (2004). Islam and Democracy: Micro-Level Indications of Compatibility, Indianna University https://doi.org/10.1177/001041400426588

16. http://www.alhewar.com/SadekDemAndShura.htm JAMM International, DOI: 105812/jamm.37334

17. Kean, T., Hamilton, L., Ben-Veniste R., Cleland, M. et al., (n.d). The 9/11 commission report, pp. 231-237

https://www.dni.gov/files/ISE/documents/DocumentLibrary/911Repo rt_0.pdf

18. Kube, C., Dilanian, K. \& De Luce, D. (2020). US has persuasive intel Taliban do not intend to abide by terms of peace deal, officials say https://www.nbcnews.com/politics/national-security/officials-u-s-haspersuasive-intel-taliban-does-not-intend-n1150051

19. Masud, E. (2008). 9/11 Unveiled, 2008, The Wisdom Fund, http://www.twf.org/Library/911Unveiled.pdf

20. Murtazashvili, J. (2016). Afghanistan: A Vicious Cycle of State Failure, Cambridge University,pp. 165-166, DOI:10.1111/gove.12195

21. Murtazashvili, J. (2019). Pathologies of Centralized State-Building, Institute for National Strategic Security, National Defense University, Vol. 8, No. 2, pp. 54-67

https://www.jstor.org/stable/10.2307/26803230

22. Neumman, E. (2015). Failed relation between Hamid Karzai and the United States United States Institute of Peace, https://www.usip.org/sites/default/files/SR373-Failed-Relationsbetween-Hamid-Karzai-and-the-United-States.pdf

23. Petersmann, S. (2021). US and NATO withdraw from an Afghanistan still at war: What you need to know, Not for Mind, https://www.dw.com/en/us-and-nato-withdraw-from-an-afghanistanstill-at-war-what-you-need-to-know/a-58092746

24. Radio Free Europe, (2020). Taliban Could 'Possibly' Seize Power After U.S. Pull-out https://www.rferl.org/a/trump-calls-talibanwarriors-chief-difficult-task-controlling-fighters/30471496.html

25. Rangin, D.S. (2017). The Inside Story, Gutman 
26. Rasanayagam, A. (1999). Taliban Fundamentalism: The Turmoils of Afghanistan World Affairs: The Journal of International Issues, 3(2), http://www.jstor.org/stable/45064653

27. Roy, O. (2002). Islamic Radicalism in Afghanistan and Pakistan, UNHCR Emergency and Security Service, https://www.refworld.org/pdfid/3c6a3f7d2.pdf

28. Sadek, J. (1998). Democracy and Shura, New York: Oxford University Press, 1998, http://www.alhewar.com/SadekDemAndShura.htm

29. Salman, N., Tezel, O., Bayramoglu, A., Meral, U. M., Akyildiz, F. et al., (2016). Retrospective Analysis of Role II Military Hospital Emergency Department Admissions in Operation Enduring Freedom of Afghanistan, Journal of Archives in Military Medicine

30. Schreer \& Waldman, (2019). Strategy on Autopilot: Resolute Support and the Continuing Failure of Western Strategy in Afghanistan, Tylore and France Group. 10.4324/9780429031038

31. Scott, Z. (2007). Literature Review on State-Building, Governance and Social Resources Centre, 3-5, http://www.gsdrc.org/docs/open/hd528.pdf

32. Siddique, B. (2012). Does Poverty Fuel Terrorism' SSRN,DOI:10.2139/ssrn.2184390

33. Singh, D. (2016). Anti-corruption Strategies in Afghanistan: An Alternative Approach, University of York, Journal of Developing Societies https://core.ac.uk/download/pdf/42413119.pdf

34. Sorkin, A. D. (2014). Afghanistan Games: Robert Gates, Obama and Karzai. The New Yorker, https://www.newyorker.com/news/amydavidson/afghanistan-games-robert-gates-obama-and-karzai

35. Stollenwerk, E. (2018) Securing Legitimacy? Perceptions of Security and ISAF's Legitimacy in Northeast Afghanistan, Journal of Intervention and Statebuilding, 12:4, 506-526, DOI: 10.1080/17502977.2018.1504855

36. Tellis, A. J. (2009). Reconciling With The Taliban, Carnegie Endowment for International Peace, pp. 5-6, https://carnegieendowment.org/files/reconciling_with_taliban.pdf

37. Tuck, C. (2013). Afghanistan: Lessons Learned from an ISAF Perspective, Small Wars Journal, https://smallwarsjournal.com/jrnl/art/afghanistan-lessons-learnedfrom-an-isaf-perspective

38. United States Signs Agreement with the Taliban, but Prospects for Its Full Implementation Remain Uncertain. (2020). American Journal of International Law, 114(3), 529-538. doi:10.1017/ajil.2020.45.

39. Watson, C. (2012) Stability, Security, Reconstruction, and Transition Operations, 2012, pp. 171, 
https://books.google.hu/books?id=JHSD2caqVzkC\&lpg

40. Weigand, F. (2017) Afghanistan's Taliban - Legitimate Jihadists or Coercive Extremists? Journal of Intervention and Statebuilding, 11:3, pp. 359-381, DOI: 10.1080/17502977.2017.1353755

41. Yusuf Ali, A. (2012). The Compatibility of Islam with Modernity: A Brief Discourse on Muslim Reformists Response, Journal of Islam in Asia

https://www.researchgate.net/publication/260877231_The_Compatibi lity_of_Islam_with_Modernity_A_Brief_Discourse_on_Muslim_Ref ormists_Response

42. Zammin, F. (2018) 'Modernity in Islamic Tradition,' Journal alManar, Vol. 76, https://doi.org/10.1515/9783110545845 